\section{AB018. Myeloid dendritic cells (mDCs) are major producers of interferon-beta in dermatomyositis and increased numbers of $\mathrm{mDCs}$ are found in hydroxychloroquine nonresponders}

\author{
Kristen L. Chen ${ }^{1,2}$, Majid Zeidi, ${ }^{1,2}$, Maria Wysocka ${ }^{2}$, \\ Nithin Reddy ${ }^{1,2}$, Arvin Jadoo ${ }^{1,2}$, \\ Muhammad M. Bashir ${ }^{1,2}$, Sarah Ahmed ${ }^{2}$, \\ Basil Patel $^{2}$, Kevin K. Zhang ${ }^{2}$, Barbara White ${ }^{3}$, \\ Victoria P. Werth ${ }^{1,2}$ \\ ${ }^{1}$ Corporal Michael J. Crescenz VAMC, Philadelphia, PA, USA; \\ ${ }^{2}$ Department of Dermatology, Perelman School of Medicine, \\ University of Pennsylvania, Philadelphia, PA, USA; ${ }^{3}$ Corbus \\ Pharmaceuticals, Inc., Norwood, MA, USA \\ Correspondence to: Victoria P. Werth. Department of Dermatology, \\ Perelman Center for Advanced Medicine, Suite 1-330A, 3400 Civic \\ Center Boulevard, Philadelphia, PA 19104, USA. \\ Email: werth@pennmedicine.upenn.edu.
}

Background: Dermatomyositis (DM) is an autoimmune disease affecting skin, skeletal muscle, and lungs. Pathogenesis is considered largely driven by interferonbeta (IFN-beta) and involves CD4+ cells and dendritic cells (DCs). (I) Quantify inflammatory cells and IFN-beta in skin; correlate with Cutaneous Dermatomyositis Disease Area and Severity Index (CDASI) scores. (II) Identify DC type contributing to refractoriness to hydroxychloroquine (HCQ). (III) Compare IFN-beta production by mDCs vs. pDCs in DM.

Methods: (I) DM skin biopsies evaluated for cells and cytokines using IHC from 12 patients with moderate- severe skin disease at baseline and after 12 weeks of therapy. (II) IHC performed on skin biopsies to compare myeloid $\mathrm{DC}(\mathrm{mDC})$ and $\mathrm{pDC}$ expression in HCQ-responders vs. -nonresponders. (III) Flow cytometry performed on PBMCs from 5 healthy controls and 5 DM patients.

Results: (I) CD4+ cells, macrophages, mDCs, and TRM cells were the most populous in DM skin, followed by CD8+ cells, mast cells, and pDCs. Change in CD4+ and CD8+ cells/HPF significantly correlated with change in CDASI scores $(r=0.82, \mathrm{P}<0.05 ; \mathrm{r}=0.81, \mathrm{P}<0.05)$. Changes in IFN-beta protein expression correlated with change in CDASI scores $(r=0.63, \mathrm{P}<0.05)$. (II) Significantly increased $\mathrm{mDCs} / \mathrm{HPF}$ found in skin of HCQ nonresponders $(\mathrm{P}<0.05)$. (III) $\mathrm{mDCs}$ and $\mathrm{pDCs}$ both produced IFN-beta in $\mathrm{DM}$ patients; pDCs were dominant producers of IFN-beta in healthy controls.

Conclusions: $\mathrm{mDCs}$ are major producers of IFN-beta in DM patients and may play an important role in DM pathogenesis.

Keywords: Dermatomyositis (DM); interferon-beta (IFN-beta); dendritic cells (DCs)

doi: 10.21037/atm.2021.AB018

Open Access Statement: This is an Open Access article distributed in accordance with the Creative Commons Attribution-NonCommercial-NoDerivs 4.0 International License (CC BY-NC-ND 4.0), which permits the noncommercial replication and distribution of the article with the strict proviso that no changes or edits are made and the original work is properly cited (including links to both the formal publication through the relevant DOI and the license). See: https://creativecommons.org/licenses/by-nc-nd/4.0/.

Cite this abstract as: Chen KL, Zeidi M, Wysocka M, Reddy N, Jadoo A, Bashir MM, Ahmed S, Patel B, Zhang KK, White B, Werth VP. Myeloid dendritic cells (mDCs) are major producers of interferon-beta in dermatomyositis and increased numbers of $\mathrm{mDCs}$ are found in hydroxychloroquine nonresponders. Ann Transl Med 2021;9(5):AB018. doi: 10.21037/atm.2021.AB018 